\title{
Stabilization of Al(III) solutions by complexation with cacodylic acid: speciation
}

\section{and binding features}

Matteo Laria ${ }^{a}$ Héctor Lozano ${ }^{a}$, Natalia Busto ${ }^{a}$, Tarita Biver ${ }^{b}$, José M. Leala, Saturnino Ibeas, ${ }^{a}$ James A. Platts ${ }^{\mathrm{c}}$, Fernando Secco ${ }^{\mathrm{b}}$, Begoña Garcia ${ }^{\mathrm{a} *}$.

a Departamento de Química, Universidad de Burgos, Plaza Misael Bañuelos s $n$, 09001 Burgos, Spain

${ }^{b}$ Dipartimento di Chimica e Chimica Industriale, Università di Pisa, Via Moruzzi 13, 56124 Pisa, Italy

${ }^{c}$ School of Chemistry, Cardiff University, Park Place, Cardiff CF10 3AT, UK.

*Corresponding author: begar @ubu.es

Abstract Aluminium ion is thought to cause a variety of neurological and skeletal disorders in man. The study of the biological processes and molecular mechanisms that underlie these pathological processes is made difficult because of the complexity of species resulting from the hydrolysis of $\mathrm{Al}^{3+}$ ion. In addition, this ion displays a strong tendency to precipitate as hydroxide. so that certain complexing agents should be envisaged in order to stabilize solutions of $\mathrm{Al}(\mathrm{III})$ under physiological conditions. In this work, we show that the common buffer cacodylic acid (dimethylarsinic acid, $\mathrm{HCac}$ ) interacts with $\mathrm{Al}(\mathrm{III})$ to give stable complexes, even at $\mathrm{pH}$ 7. After preliminary analyses of the speciation of the metal ion and also of the ligands, a systematic study of the formation of different $\mathrm{Al} / \mathrm{Cac}$ complexes at different $\mathrm{pH}$ values has been conducted. UV-Vis titrations, mass spectrometry and NMR measurements were performed to enlighten the details of the speciation and stoichiometry of $\mathrm{Al} / \mathrm{Cac}$ complexes. The results altogether show that $\mathrm{Al} / \mathrm{Cac}$ dimer complexes prevail, but monomer and trimer forms are also present. Interestingly, it was found that cacodylate promotes the formation of such relatively simple complexes, even under conditions where the polymeric form, $\mathrm{Al}_{13} \mathrm{O}_{4}(\mathrm{OH})_{24}{ }^{7+}$, should predominate. The results obtained can be useful to study the reactivity of aluminium ion in the biological environment. 
Keywords: Aluminium complexes, dimethylarsinic acid, Al(III) speciation, ${ }^{27} \mathrm{Al}-\mathrm{NMR}$.

\section{Introduction}

Aluminium ion is prone to forming a variety of hydrolytic species, ${ }^{1}$ including the $\mathrm{Al}_{13} \mathrm{O}_{4}(\mathrm{OH})_{24}{ }^{7+}$ polymeric form; it exhibits certain tendency to precipitate as $\mathrm{Al}(\mathrm{OH})_{3}$ even at relatively acidic $\mathrm{pH}$, and reacts with oxygen-containing ligands. ${ }^{2,3}$ Many studies have enlightened the importance of aluminium in biological fluids and its ability to bind biosubstrates, both outside and inside the cell, associating its presence to health diseases. ${ }^{4-8}$ The presence of different hydrolytic forms entails involvement of a number of equilibria and, consequently, many other possible complexes. These features render aluminium a very complex system.

Dimethylarsinic (cacodylic) acid, $\left(\mathrm{CH}_{3}\right)_{2} \mathrm{AsOOH}$, is largely used to study the interaction of biological molecules with organic dyes or metal ions. ${ }^{9}$ Cacodylic acid $\left(\mathrm{HCac}, \mathrm{pK}_{\mathrm{A}}=6.20 .1\right.$ ), with a buffer window ranging $\mathrm{pH} 5.2-7.2,{ }^{10-13}$ is quite a valuable tool to study nucleic acids and proteins under physiological conditions. On the other side, the cacodylate anion is unreactive towards many divalent metal ions; ${ }^{14}$ for this reason it is thought to ensure buffer inactivity for many biomolecule/metal ion (or metal complex) systems. On the other hand, there is evidence that the cacodylate anion can bind metal ions such as $\mathrm{Sb}(\mathrm{III}), \mathrm{Bi}(\mathrm{III}),{ }^{15} \mathrm{Pd}(\mathrm{II}){ }^{16}$ and some rare earth metals. ${ }^{17}$ Formation of $\mathrm{Al}(\mathrm{III}) / \mathrm{Cac}$ complex ${ }^{18}$ and, more recently, the synthesis of complexes of the dimethylarsinate anion and metal ions of the XIII group ( $\mathrm{Al}, \mathrm{Ga}, \mathrm{In}, \mathrm{Tl})$ has been 
reported. ${ }^{19}$ However, to the best of our knowledge, systematic thermodynamic studies of the aluminium/cacodylic acid system in solution under different experimental conditions are still lacking. This work focuses on the study of the $\mathrm{Al}(\mathrm{III}) / \mathrm{Cac}$ system at different $\mathrm{pH}$ values to infer the nature and strength of the interaction between $\mathrm{Al}(\mathrm{III})$ and the ligand and to assess the possible use of cacodylate to provide $\mathrm{Al}(\mathrm{III})$ buffered solutions for biochemical studies at neutral $\mathrm{pH}$.

\section{Materials and Method}

\subsection{Materials}

The aluminium source was the $\mathrm{Al}\left(\mathrm{ClO}_{4}\right)_{3} \cdot 8 \mathrm{H}_{2} \mathrm{O}$ solid salt supplied by Fluka. Aluminium stock solutions were prepared by dissolving appropriate amounts of the solid in $\mathrm{HClO}_{4}$ solutions, brought at $\mathrm{pH}=2$ to avoid hydroxide precipitation. The standardization of aluminium stock solutions was carried out through EDTA titrations, using Eriochrome Black-T as an indicator. Briefly, a calibrated excess of EDTA was added to an aliquot of the aluminium solution; the mixture was then boiled and, after addition of acetate buffer $(\mathrm{pH}=6)$, it was back titrated with a standardized solution of $\mathrm{Zn}^{2+}$. Stock solutions of sodium dimethylarsinate $\left(\left(\mathrm{CH}_{3}\right)_{2} \mathrm{AsOONa}, \mathrm{NaCac}-\mathrm{Carlo}\right.$ Erba, purity 96\%) were prepared by dissolving weighed amounts of the solid in water and titrated with $\mathrm{NaOH}$. The ionic strength (I) of the working solutions was kept constant at $0.1 \mathrm{M}$ with sodium perchlorate (Merck), while the desired $\mathrm{pH}$ was attained by small additions of $\mathrm{NaOH}$ and $\mathrm{HClO}_{4}$. All of the reactants were analytical grade and were used without further purification. Ultra-pure water from a Millipore MILLI-Q water purification system was used to prepare the solutions and as a reaction medium. 


\subsection{Methods}

$\mathrm{pH}$ measurements were performed with a Metrohm 713 (Herisau, Switzerland) $\mathrm{pH}-$ meter equipped with a combined glass electrode. Spectrophotometric titrations were carried out with a Shimadzu 2450-Spectrophotometer, equipped with jacketed cell holders (thermostat precision $0.1{ }^{\circ} \mathrm{C}$ ). All experiments were conducted at $25{ }^{\circ} \mathrm{C}$. Titrations of $\mathrm{Al}(\mathrm{III}) / \mathrm{Cac}$ system were performed in the batch-wise mode at the desired $\mathrm{pH}$ values and ionic strength $0.1 \mathrm{M}\left(\mathrm{NaClO}_{4}\right)$. Different samples were prepared for different metal-to-ligand ratio and left for $24 \mathrm{~h}$ to reach equilibration. For each sample, the absorbance spectrum was recorded in the 190-300 nm range (path-length cell 1 $\mathrm{cm}$ ) and the binding parameters were evaluated averaging the results obtained at different selected wavelengths in the 205-193 nm range. Mass spectra in double distilled water recorded for samples at $C_{L} / C_{M}=1\left(C_{M}=0.2 \mathrm{mM}\right), C_{L}$ and $C_{M}$ being, respectively, the cacodylate and aluminium ion concentrations, were obtained by means of a TOF Mass Spectrometer Bruker Maxis Impact, with electrospray ionization (ESI). NMR samples were prepared by dissolving in $0.5 \mathrm{~mL}$ of the respective oxygen-free deuterated solvent the proper amount of $\mathrm{Al}^{3+}$ to $5 \mathrm{mM}$ working solutions with the corresponding amount of Sodium Cacodylate for each $C_{L} / C_{M}$ ratio studied. Unless otherwise stated, the spectra were recorded at $298 \mathrm{~K}$ on a Varian Unity Inova-400 (399.94 MHz for ${ }^{1} \mathrm{H}$; $104.21 \mathrm{MHz}$ for ${ }^{27} \mathrm{Al}$ ). Typically, 1D ${ }^{1} \mathrm{H}$ NMR spectra were acquired with 32 scans into $32 \mathrm{k}$ data points over $16 \mathrm{ppm}$ spectral width; the spectra of ${ }^{27} \mathrm{Al} \mathrm{NMR}$ were acquired with 16 scans. ${ }^{1} \mathrm{H}$ chemical shifts were referenced internally to TMS via 1,4 -dioxane in $\mathrm{D}_{2} \mathrm{O}(\delta=3.75 \mathrm{ppm})$. Chemical shift values are reported in ppm. All of the NMR data processing were carried out using MestReNova version 6.1.1. 
DFT calculations were carried out using B3LYP functional to optimize some proposed structures for the aluminium-sodium cacodylate complex; this procedure was used satisfactorily for DFT calculations of metals, $\{$ Lashkari, 2004, DFT studies of pyridine corrosion inhibitors in electrical double layer: solvent', substrate', and electric field effects $\}^{20}$ applying 6-31G(d) basis set to $\mathrm{C}, \mathrm{H}$ and $\mathrm{O}$ atoms. A double zeta function (LANL2DZ) was used for $\mathrm{Al}$ and As, including effective core potential calculation (ECP) for core electrons, diminishing the computational calculation costs. Water was used as solvent. All calculations and data analyses were performed with Gaussian 09. ${ }^{21}$

\section{Results and Discussion}

\subsection{Evaluation of the $\mathrm{pK}_{\mathrm{A}, 1}$ and $\mathbf{p K _ { \mathrm { A } , 2 }}$ acidity constants of cacodylic acid}

Cacodylic acid is a diprotic acid; its diprotonated form is here denoted as $\mathrm{H}_{2} \mathrm{Cac}^{+}$. This species undergoes acid dissociation according to eqns (1) and (2), which are characterized by the acid dissociation constants $\mathrm{K}_{\mathrm{A}, 1}$ and $\mathrm{K}_{\mathrm{A}, 2}$ respectively.

$\mathrm{H}_{2} \mathrm{Cac}^{+}+\mathrm{H}_{2} \mathrm{O} \rightleftarrows \mathrm{HCac}+\mathrm{H}_{3} \mathrm{O}^{+}$

$\mathrm{HCac}+\mathrm{H}_{2} \mathrm{O} \rightleftarrows \mathrm{Cac}^{-}+\mathrm{H}_{3} \mathrm{O}^{+}$

The ${ }^{1} \mathrm{H}-\mathrm{NMR}$ spectra of cacodylate shows a singlet signal ascribable to the methyl groups of NaCac. The location of these peaks very much depends on the medium acidity for the higher acidity, the higher the chemical shift of the peaks (Fig. 
$1 \mathrm{~A})$.

The $\mathrm{pK}_{\mathrm{A}, 1}$ and $\mathrm{pK} \mathrm{A}_{\mathrm{A}, 2}$ values have been determined by the chemical shift analysis of the ${ }^{1} \mathrm{H}-\mathrm{NMR}$ singlets of sodium cacodylate at different values of the $\mathrm{pH}$ and the acidity function $\mathrm{H}_{0}$ (Fig. 1B); the latter function was employed at the highest acidity levels used, outside the boundary of the $\mathrm{pH}$ scale. ${ }^{22}$ The two dissociation constants of cacodylic acid were evaluated according to eqn (3):

where в and $\mathrm{BH}+$ represent the chemical shift of the basic and acidic forms, respectively, and that at an intermediate acid concentration, according to species shown in eqns. (1) and (2). The chemical shift of the basic form (в) at $\mathrm{pH}=8$ is not well defined, thereby to evaluate ${ }_{\mathrm{B}}$ and $\mathrm{pK}_{\mathrm{A}, 2}$ an iteration procedure had to be used. To determine $\mathrm{pK}_{\mathrm{A}, 1}$, eqn. (3) was applied directly by adopting for в the chemical shift at $\mathrm{pH}=4$, whereas that for $\mathrm{BH}+$ was taken as the highest value in Fig. 1B. The continuous line denotes the outcome of the two fittings. The $\mathrm{pK}_{\mathrm{A}, 1}$ and $\mathrm{pK}_{\mathrm{A}, 2}$ values obtained, $1.3 \quad 0.2$ and 6.20 .1 respectively, were in reasonable good agreement with the literature values, $\mathrm{pK}_{\mathrm{A}, 1}=$ $1.1^{10}$ and $2.6^{23}$, and $\mathrm{pK}_{\mathrm{A}, 2}=6.2^{10-13}$. Fig. $1 \mathrm{C}$ shows the speciation curves of cacodylic acid. 


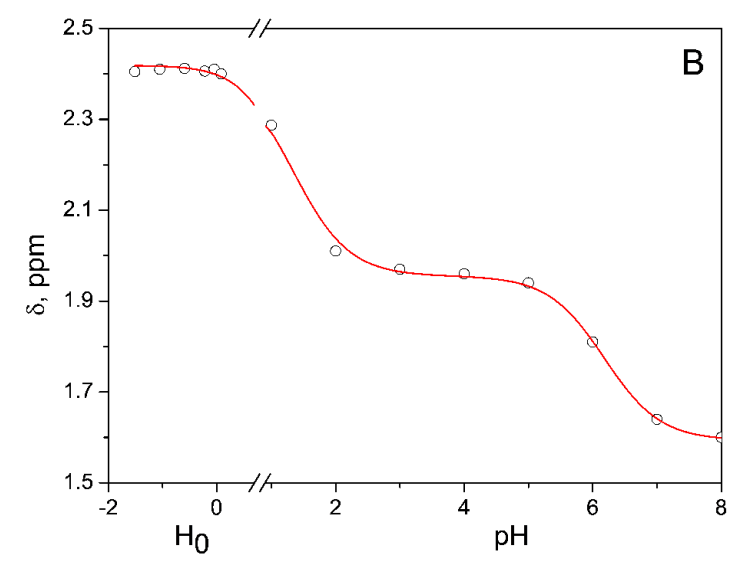




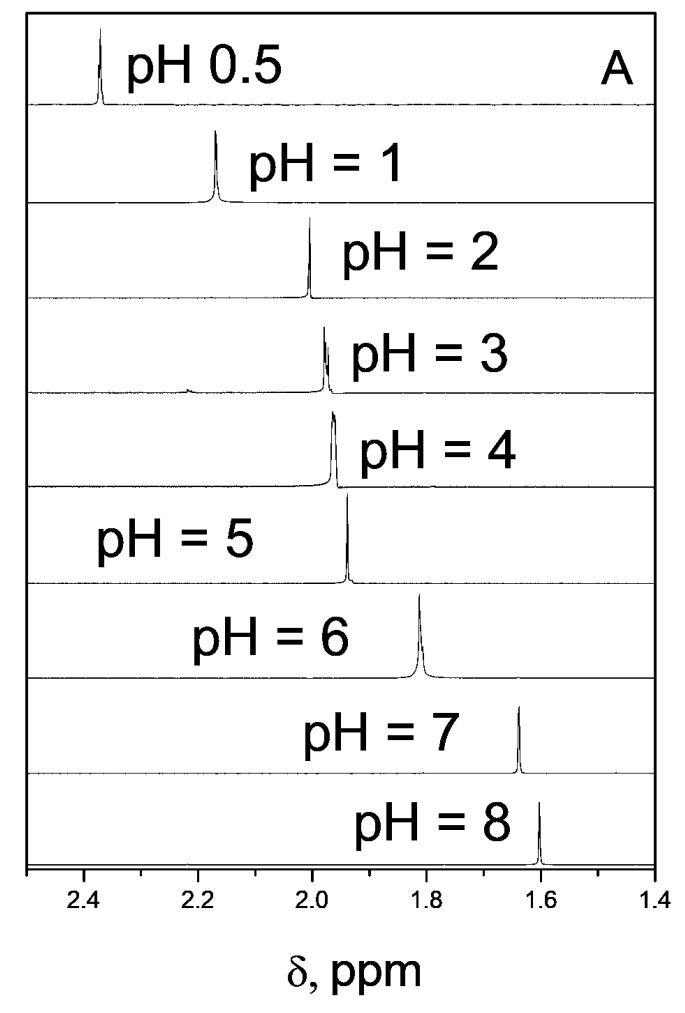




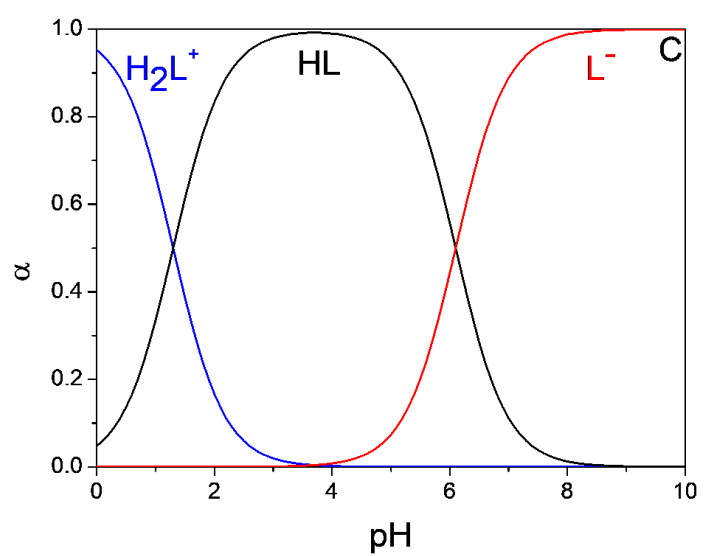

Fig. 1 (A) ${ }^{1} \mathrm{H}-\mathrm{NMR}$ spectra at $\mathrm{pH}=0.5,1,2,3,4,5,6,7$ and 8. (B) $\delta$ versus $\mathrm{pH}$ (or $\mathrm{H}_{0}$ ) plot corresponding to $\mathrm{pK}_{\mathrm{A}, 1}$ and $\mathrm{pK}_{\mathrm{A}, 2} . \mathrm{C}_{\mathrm{L}}=5.00 \times 10^{-3} \mathrm{M}$. (C) Speciation of cacodylic acid $\left(\mathrm{pK}_{\mathrm{A}, 1}=1.3\right.$, $\left.\mathrm{pK}_{\mathrm{A}, 2}=6.1\right) . \mathrm{I}=0.1 \mathrm{M}\left(\mathrm{NaClO}_{4}\right), \mathrm{T}=25.0{ }^{\circ} \mathrm{C}$.

As for the absorbance measurements, Fig. S1 (ESI) shows the spectra of cacodylic acid at different $\mathrm{pH}$ values $\left(\mathrm{I}=0.1 \mathrm{M}, \mathrm{NaClO}_{4}\right)$. The change in absorbance 
upon titration within the 2-10 $\mathrm{pH}$ range (Fig. S1, inset) has enabled us to evaluate the second acid dissociation constant of cacodylic acid, the resulting value being: $\mathrm{pK}_{\mathrm{A}, 2}=$ $6.0 \pm 0.2$. Below $\mathrm{pH} \mathrm{3}$, the shift of the $193 \mathrm{~nm}$ band to lower wavelengths can be ascribed to formation of the $\mathrm{H}_{2} \mathrm{Cac}^{+}$species.

\subsection{Speciation of aluminium forms}

Fig. 2 shows the ${ }^{27} \mathrm{Al}-\mathrm{NMR}$ spectra in the $1-6 \mathrm{pH}$ range (above $\mathrm{pH} 6$ the measurements could not be executed because aluminium precipitates). NMR measurements show that the hexaaquoaluminium(III) ion, $\mathrm{Al}(\mathrm{OH}) 6^{3+}$, prevails between pH 1 and 4. The wide band in ${ }^{27} \mathrm{Al}-\mathrm{NMR}$ spectra observed between $\mathrm{pH} 5$ and 6 can be ascribed to the polycation species $\mathrm{Al}_{13} \mathrm{O}_{4}(\mathrm{OH})_{24}{ }^{7+}$ (also denoted as $\mathrm{Al}_{13}$-mer). ${ }^{24}$ Between $\mathrm{pH} 6$ and 7, partial or full neutralization of the polymer charge promotes aggregation of $\mathrm{Al}_{13}$-mer, which tends to precipitate, and formation of more complex polymeric forms, such as $\mathrm{Al}_{2} \mathrm{O}_{8} \mathrm{Al}_{28}(\mathrm{OH})_{56}\left(\mathrm{H}_{2} \mathrm{O}\right)_{26}{ }^{18+}$ (also known as $\mathrm{Al}_{30}$-mers) is likely to occur..$^{25,26}$ 


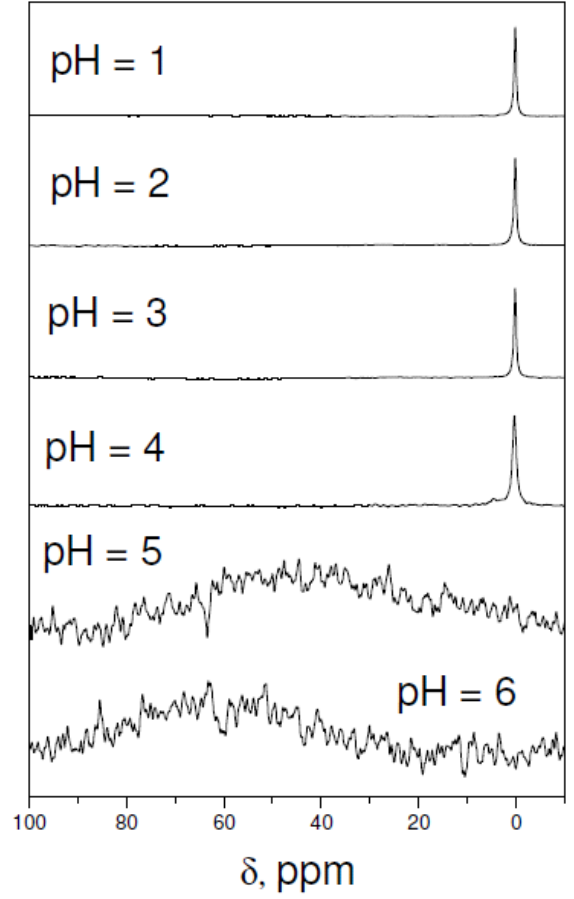

Fig. $2{ }^{27} \mathrm{Al}-\mathrm{NMR}$ spectra of $\mathrm{Al}(\mathrm{III})$ at different $\mathrm{pH}$ values. $\mathrm{C}_{\mathrm{M}}=5.00 \times 10^{-3} \mathrm{M}, \mathrm{I}=0.1 \mathrm{M}\left(\mathrm{NaClO}_{4}\right)$ and $\mathrm{T}=25.0^{\circ} \mathrm{C}$. The $\mathrm{pH}$-independent narrow peak at $\delta$ (roughly) $0 \mathrm{ppm}$, is ascribed to the monomeric species $\mathrm{Al}^{3+}$, whereas the broad band observed at $\mathrm{pH} 5$ and 6 is the $\mathrm{Al}_{13} \mathrm{O}_{4}(\mathrm{OH})_{24}{ }^{7+}$ polymer.

The NMR findings are corroborated by literature data. The molar fraction $(\beta)$ 
of the $\mathrm{Al}^{3+}$ hexahydrate ion and its hydrolytic forms can be calculated according to eqn $(4):^{1}$

where $\mathrm{I}$ is the ionic strength of the medium, $\mathrm{Q}_{\mathrm{xy}}$ is the equilibrium ratio related to formation of the hydrolyzed $\mathrm{Al}_{\mathrm{x}}(\mathrm{OH})_{\mathrm{y}}{ }^{(3 \mathrm{x}-\mathrm{y})+}$ species $\left(\mathrm{xAl}+\mathrm{yH}_{2} \mathrm{O} \quad \mathrm{Al}_{\mathrm{x}}(\mathrm{OH})_{\mathrm{y}}{ }^{(3 \mathrm{x}-\mathrm{y})+}+\right.$ $\mathrm{yH}^{+}$) and $\mathrm{K}_{\mathrm{xy}}$ is the relevant thermodynamic equilibrium constant, $\boldsymbol{a}$ and $\boldsymbol{b}$ being fitting parameters and $\mathrm{m}_{\mathrm{x}}$ is the overall aluminium molality. ${ }^{1}$ This calculation was performed at different $\mathrm{pH}$ values and metal concentrations using the Octave program, ${ }^{27}$ yielding the distribution plots shown in Fig. 3. This figure shows that the amount of dimer and trimer species is negligible and that the predominant species in the 4.5 to $8.0 \mathrm{pH}$ range is $\mathrm{Al}_{13} \mathrm{O}_{4}(\mathrm{OH})_{24}{ }^{7+}$ whereas $\mathrm{Al}(\mathrm{OH})_{4}{ }^{-}$is the prevailing species above $\mathrm{pH} 8$. 


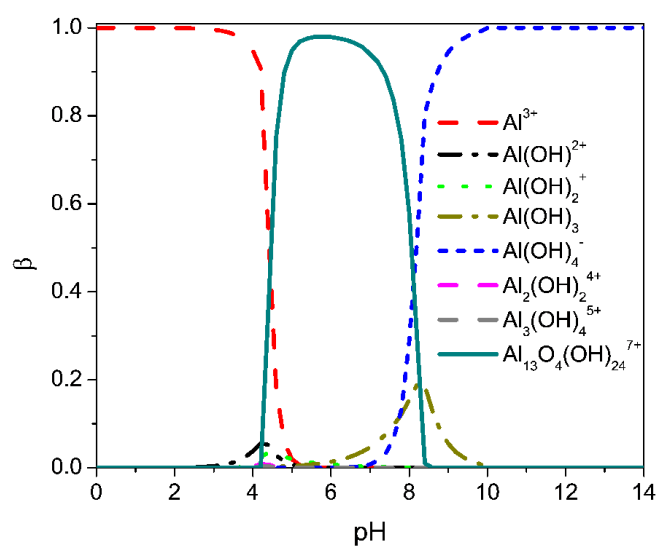

Fig. 3 Speciation of $\mathrm{Al}(\mathrm{III}) . \mathrm{C}_{\mathrm{M}}=1.00 \times 10^{-3} \mathrm{M}, \mathrm{I}=0.1 \mathrm{M}$ and $\mathrm{T}=25.0^{\circ} \mathrm{C}$.

The results from Fig. 3 are compared in Fig. S2 (A and B, ESI) with other results obtained for $\mathrm{Al}^{3+}$ concentrations of $1.0 \times 10^{-4}$ and $1.0 \times 10^{-5} \mathrm{M}$, showing that polymeric species are absent in dilute solutions. Additionally, an increase in the aluminium concentration $\left(\mathrm{C}_{\mathrm{M}}\right)$ causes a small diminution of $\beta_{\mathrm{Al}} \mathrm{l}^{3+}$ and a sharp increase of the polymeric form $\mathrm{Al}_{13} \mathrm{O}_{4}(\mathrm{OH})_{24}{ }^{7+}$.

\subsection{The aluminium/cacodylate system}

Mass spectrometry. The different number of peaks recorded at different $\mathrm{pH}$ reveals the complexity of the distribution of the aluminium species (Fig. S3, ESI). We 
focused the attention on the most representative peaks in the spectrum and determined four types of species: (1) free cacodylate, which is predominant and in particular the $[\mathrm{HCac}+\mathrm{H}]^{+}(\mathrm{m} / \mathrm{z}=139)$ and $[\mathrm{NaCac}+\mathrm{H}]^{+}(\mathrm{m} / \mathrm{z}=161)$ adducts and other peaks reported in literature, ${ }^{28,}{ }^{29}$ such as $\mathrm{m} / \mathrm{z}=277,259,299,281,437$ and 419 (corresponding to $\left[\mathrm{H}_{2} \mathrm{Cac}_{2}+\mathrm{H}\right]^{+}, \quad\left[\mathrm{H}_{2} \mathrm{Cac}_{2}+\mathrm{H}-\mathrm{H}_{2} \mathrm{O}\right]^{+}, \quad\left[\mathrm{H}_{2} \mathrm{Cac}_{2}+\mathrm{Na}\right]^{+}, \quad\left[\mathrm{H}_{2} \mathrm{Cac}_{2}+\mathrm{Na}-\right.$ $\left.\left.\mathrm{H}_{2} \mathrm{O}\right]^{+}, \quad\left[\mathrm{H}_{3} \mathrm{Cac}_{3}+\mathrm{Na}\right]^{+}, \quad\left[\mathrm{H}_{3} \mathrm{Cac}_{3}+\mathrm{Na}-\mathrm{H}_{2} \mathrm{O}\right]^{+}\right)$, respectively; (2) perchlorate and cacodylate salt clusters: $\left[\mathrm{Na}\left(\mathrm{NaClO}_{4}\right)_{\mathrm{x}}\right]^{+}(\mathrm{m} / \mathrm{z}=145,267,389)$ and $\left[\mathrm{Na}(\mathrm{NaCac})_{\mathrm{x}}\right](\mathrm{m} / \mathrm{z}$ $=183,343,503,663)$; (3) $\mathrm{Al}$ uncomplexed forms: $\mathrm{Al}(\mathrm{OH})_{2}\left(\mathrm{H}_{2} \mathrm{O}\right)_{\mathrm{v}}{ }^{+}(\mathrm{m} / \mathrm{z}=79,115$, 133); $\mathrm{Al}_{2} \mathrm{O}\left(\mathrm{OH}_{2}\right)_{3}{ }^{+}(\mathrm{m} / \mathrm{z}=121)$ and (4) $\mathrm{Al} / \mathrm{Cac}$ complexes. By analogy with the formulation of aluminium(III) of aquo-chloro-complexes, we adopt the general formula $\mathrm{Al}_{\mathrm{x}} \mathrm{O}_{\mathrm{y}}(\mathrm{OH})_{\mathrm{z}} \mathrm{Cac}_{\mathrm{u}}\left(\mathrm{H}_{2} \mathrm{O}\right)_{\mathrm{v}}{ }^{\mathrm{n}+}$ for the aluminium/cacodylate complexes. ${ }^{30}$ The distribution of the different forms is shown in Fig. 4, whereas the respective formulas are summarized in the Electronic Supporting Information (Table 1 ESI). 


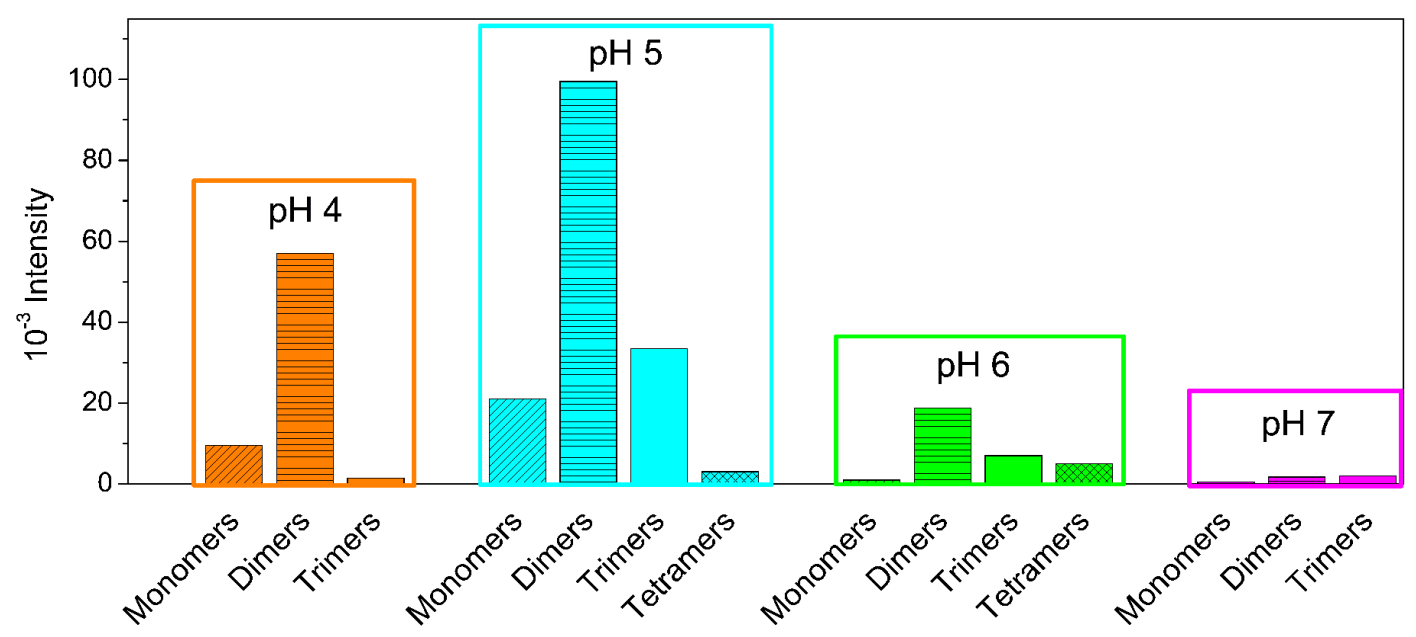

Fig. 4 Distribution of the different forms of Al/Cac complexes at different pHs. $C_{L}=C_{M}=2.00 \times$ $10^{-4} \mathrm{M}$ and $\mathrm{T}=25.0^{\circ} \mathrm{C}$.

However, it should be pointed out here that assignment of the proper formula is prone to ambiguity. ${ }^{31}$ In the first place, the $(\mathrm{OH})_{2}{ }^{2-}$ and $\mathrm{O}\left(\mathrm{OH}_{2}\right)^{2-}$ patterns, having the same value of the $\mathrm{m} / \mathrm{z}$ ratio, cannot be differentiated. Therefore, $\mathrm{Al}_{2} \mathrm{O}(\mathrm{OH})$ $\mathrm{Cac}_{2}\left(\mathrm{H}_{2} \mathrm{O}\right)^{+}$could be replaced by $\mathrm{Al}_{2}(\mathrm{OH})_{3} \mathrm{Cac}_{2}{ }^{+}$. Moreover, some peaks can be assigned to either a free or a bound aluminium species. For instance, the peak at $\mathrm{m} / \mathrm{z}=$ 121 can be ascribed to the free species $\mathrm{Al}_{2} \mathrm{O}(\mathrm{OH})_{3}{ }^{+}$and to the $\mathrm{Al}_{2} \mathrm{O}(\mathrm{OH}) \mathrm{Cac}\left(\mathrm{H}_{2} \mathrm{O}\right)_{\mathrm{v}}{ }^{2+}$ 
complex, and the peaks at 301 and 319 to the $1: 2$ complex $\operatorname{AlCac}_{2}\left(\mathrm{H}_{2} \mathrm{O}\right)_{\mathrm{v}}{ }^{+}$or to the 3:1 $\mathrm{Al}_{3} \mathrm{O}(\mathrm{OH}) \mathrm{Cac}\left(\mathrm{H}_{2} \mathrm{O}\right)_{\mathrm{v}}{ }^{+}$complex. The theoretical (see below) and literature ${ }^{30-34}$ data will allow us to suggest the most stable form.

At $\mathrm{pH} \mathrm{4,5}$ and 6 the most intense peaks are those associable to the dimeric forms. On the other hand, monomeric species are mainly present not only at $\mathrm{pH} 5$, but also at $\mathrm{pH}$ 4. Trimeric forms display lower intensity signals and are detected at $\mathrm{pH} \mathrm{5,6}$ and 7. In particular, the signal at $\mathrm{pH} 7$ is lower than those detected at $\mathrm{pH} 5$ and 6 , concurrent with the weakening of the interaction of cacodylate at neutral $\mathrm{pH}$, observed in the NMR experiments as described below.

The high abundance of dimeric complexes contrasts with the $\beta$ values, indicating rather modest presence of dimers when cacodylate is absent (Fig. 3). To support this view, previous studies ${ }^{30-34}$ on aluminium complexes with organic ligands have shown that $\mathrm{Al}_{2} \mathrm{O}(\mathrm{OH})_{3}{ }^{+}$yields a small peak, suggesting that the dimeric aluminium free species are only poorly present in solution. Hence, it can be surmised that the presence of cacodylate induces, in addition to the 1:1 complex , the formation of ligand bound dimeric and (to a lesser extent) also trimeric and tetrameric species. Furthermore, the fact that the peaks of these species are present also at $\mathrm{pH} 5$ and 6 , where, in the absence of ligand, the polymeric form $\mathrm{Al}_{13}$-mer is far prevailing, suggests that the ligand induces the disintegration of $\mathrm{Al}_{13}$-mer to give smaller molecules.

${ }^{27} \mathrm{Al}-\mathrm{NMR}$ and ${ }^{1} \mathrm{H}-\mathrm{NMR}$ studies. Fig. 5A shows the ${ }^{27} \mathrm{Al}-\mathrm{NMR}$ spectra for $\mathrm{Al} / \mathrm{Cac}$ in the $\mathrm{pH} 1-7$ range. Between $\mathrm{pH} 1$ and 2, only the signal corresponding to free $\mathrm{Al}^{3+}$ was observed at $0 \mathrm{ppm}$. In addition to the signal at $0 \mathrm{ppm}$, at $\mathrm{pH} 3$ and 4, two further signals, at 2 and $4 \mathrm{ppm}$, were observed, the former remaining very modest at the two $\mathrm{pH}$ values. The second displays a remarkable increase in intensity on going 
from $\mathrm{pH} 3$ to $\mathrm{pH}$ 4. At $\mathrm{pH} 5$ and 6 , a wide band is observed at 8 and $12 \mathrm{ppm}$, respectively. At $\mathrm{pH} 7$, the centre of the band is shifted to $60 \mathrm{ppm}$.
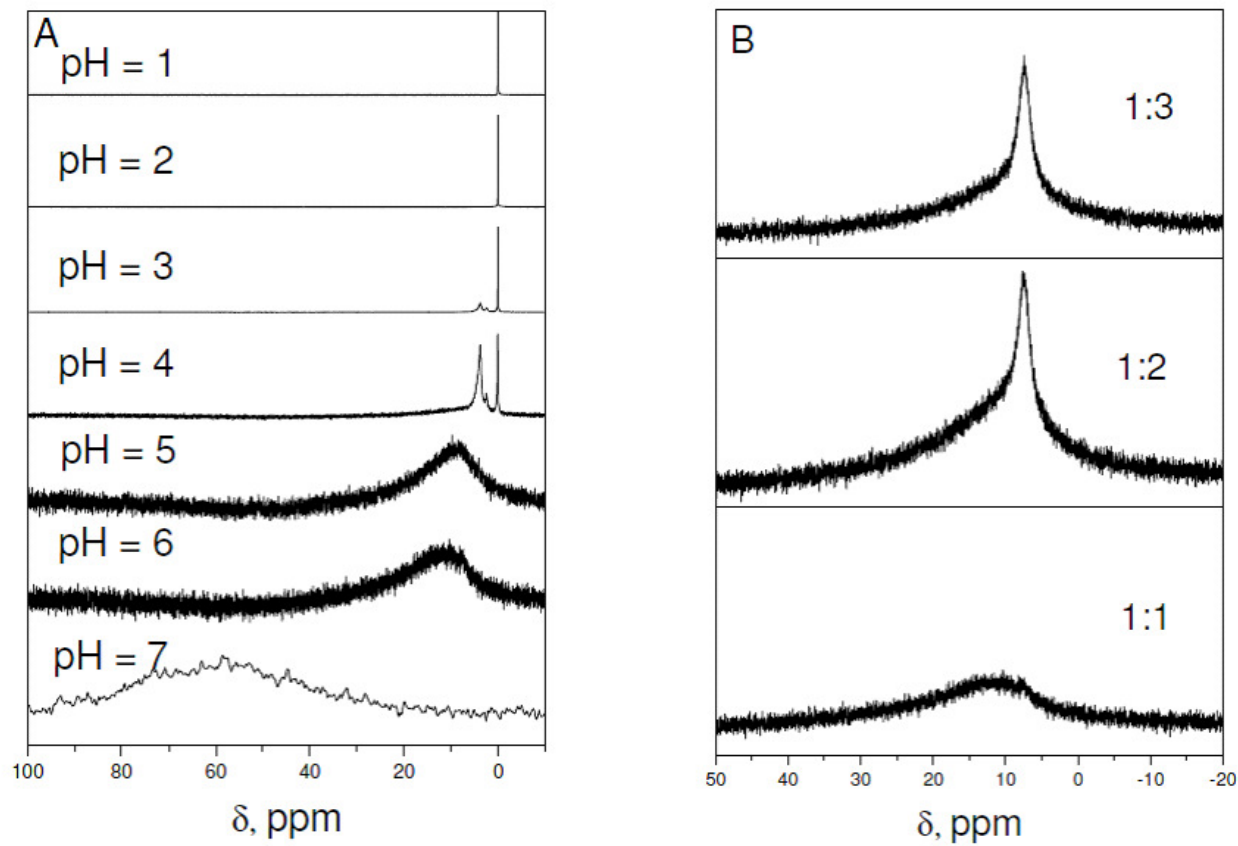

Fig. $5{ }^{27} \mathrm{Al}$-NMR spectra for (A) Al/NaCac system at $\mathrm{pH}=1,2,3,4,5,6$ and 7, $\mathrm{C}_{\mathrm{M}} / \mathrm{C}_{\mathrm{L}}=1: 1$ (B) $\mathrm{Al} / \mathrm{NaCac}$ system at $\mathrm{C}_{\mathrm{M}} / \mathrm{C}_{\mathrm{L}}=1: 1,1: 2$ and $1: 3, \mathrm{C}_{\mathrm{M}}=5.00 \times 10^{-3} \mathrm{M}, \mathrm{pH}=6.0, \mathrm{I}=0.1 \mathrm{M}\left(\mathrm{NaClO}_{4}\right)$ and $\mathrm{T}=25^{\circ} \mathrm{C}$. 
Fig. 6 shows the ${ }^{1} \mathrm{H}-\mathrm{NMR}$ spectra of the $\mathrm{Al} / \mathrm{NaCac}$ system recorded at different $\mathrm{pH}$ values and different times. The peak of the free ligand (circled ), and other peaks are displayed in the $4 \mathrm{pH} 7$ range, which are associated to the bound cacodylate. The whole of the ${ }^{27} \mathrm{Al}-\mathrm{NMR}$ and ${ }^{1} \mathrm{H}-\mathrm{NMR}$ experiments have contributed to interpret the behaviour of the aluminium/cacodylate system at different $\mathrm{pH}$ values.

$$
\mathbf{t}=10 \mathrm{~min}
$$
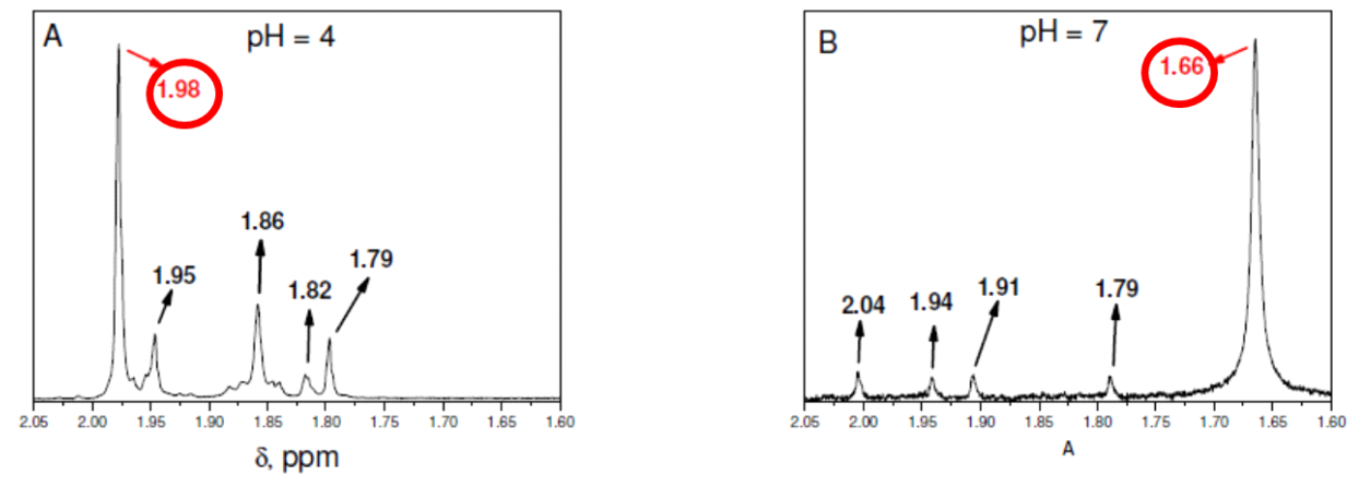

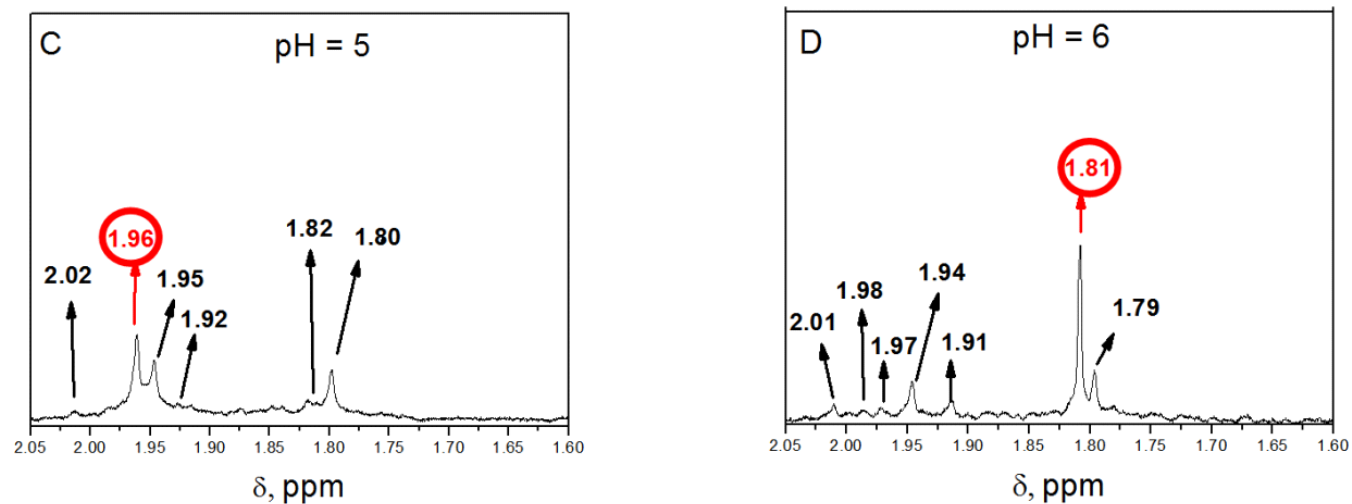

$\mathbf{t}=\mathbf{2 4 h}$
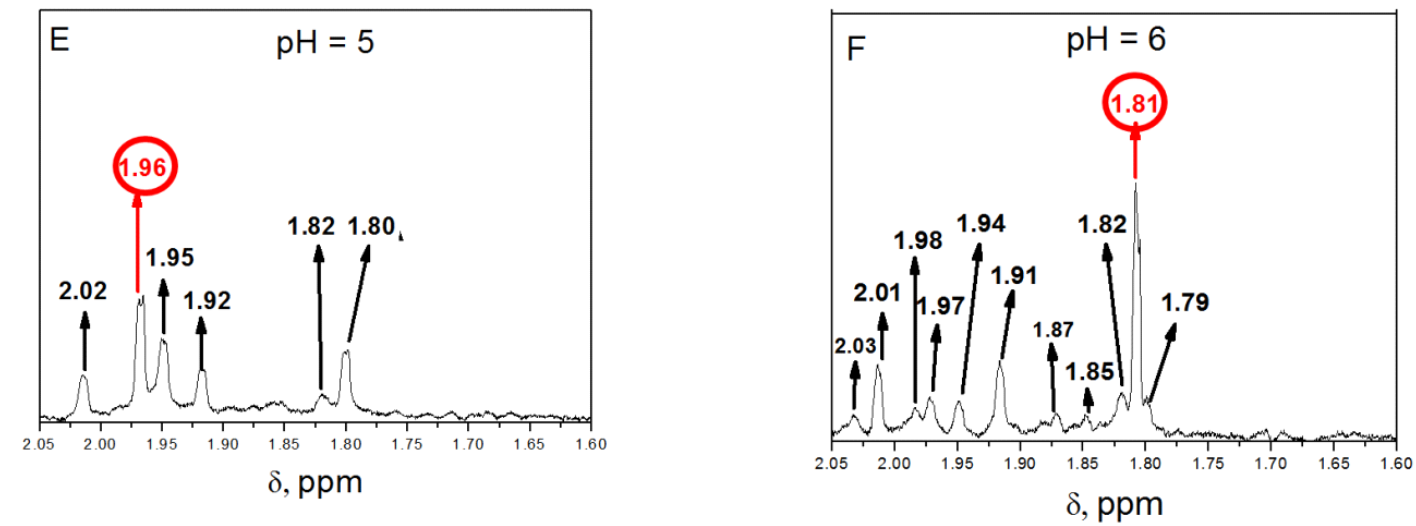

Fig. $6{ }^{1} \mathrm{H}-\mathrm{NMR}$ kinetics of $\mathrm{Al} / \mathrm{NaCaC}$ complex at $\mathrm{t}=10 \min (\mathrm{A}, \mathrm{B}, \mathrm{C}$ and $\mathrm{D})$ and $\mathrm{t}=1$ day $(\mathrm{E}$ and F). $\mathrm{C}_{\mathrm{M}}=\mathrm{C}_{\mathrm{L}}=5.00 \times 10^{-3} \mathrm{M}, \mathrm{I}=0.1 \mathrm{M}\left(\mathrm{NaClO}_{4}\right), \mathrm{pH}=4-7$ and $\mathrm{T}=25{ }^{\circ} \mathrm{C}$. Circled chemical shift stands for free cacodylate at every $\mathrm{pH}$.

No $\mathrm{Al} / \mathrm{Cac}$ complex is formed at $\mathrm{pH} 1$ and 2. However little amounts of complex are detected at $\mathrm{pH} 3$ and the extent of binding becomes more and more important as the $\mathrm{pH}$ is raised, in agreement with the general behaviour displayed by complex formation reactions of metal ions with ligands protonated at the reaction site.

Concerning the data at $\mathrm{pH} 4$, comparison of the ${ }^{27} \mathrm{Al}-\mathrm{NMR}$ spectra of free (Fig. 2) and bound (Fig. 5A) aluminium shows a remarkable increase of the peak at 4 ppm, 
which can be associated to the dimeric aluminium/cacodilate form. ${ }^{35,36}$ In the ${ }^{1} \mathrm{H}-\mathrm{NMR}$ spectrum (Fig. 6A), the singlet at 1.86 can be associated to the monomeric $\mathrm{AlCac}^{2+}$ form, since $\delta=1.86 \mathrm{ppm}$ is associated to the $\mathrm{Al}^{3+}$ ion according to the data of Fig. 5A. The two peaks at 1.95 and 1.79 , having the same intensity, most likely correspond to a dimeric form, in which the two methyl groups have different environment. Also other small peaks are present, in particular in the $1.88-1.85 \mathrm{ppm}$ range and at $1.82 \mathrm{ppm}$, which can be related to other monomeric species, such as $\mathrm{Al}(\mathrm{OH}) \mathrm{Cac}^{+}$.

The broad peak observed at $\mathrm{pH} 5$ and 6 in the ${ }^{27} \mathrm{Al}-\mathrm{NMR}$ experiments (Fig. 5A) should be associated to the sum of dimeric, trimeric and other polymeric species coming from the decomposition of the $\mathrm{Al}_{13}$ aggregate associated to the broad peak at 60 ppm (Fig. 2). In addition, ${ }^{27} \mathrm{Al}-\mathrm{NMR}$ spectra recorded at $\mathrm{pH} 6$ for $\mathrm{C}_{\mathrm{L}} / \mathrm{C}_{\mathrm{M}} 1,2$ and 3 show constriction of the broad peak, with signal increase at $7.5 \mathrm{ppm}$ (Fig. 5B). This behaviour agrees well with further disintegration of the $\mathrm{Al}_{13}$-mer in the presence of an excess of cacodylate. The ${ }^{1} \mathrm{H}-\mathrm{NMR}$ experiments show that the peak at $1.86 \mathrm{ppm}$, present at $\mathrm{pH} 4$, disappears when the solution $\mathrm{pH}$ is raised (spectra at $\mathrm{pH} 5$ and 6 in Figs. 6C and 6D), while the peaks at 1.95 and $1.80 \mathrm{ppm}$ exhibit remarkable intensity. Moreover, a very slow kinetic process is observed, followed by the increase of two peaks at 2.01 and $1.92 \mathrm{ppm}$, of same intensity (Figs. 6E and 6F). Therefore, we can surmise that the interaction between aluminium and cacodylate is the summation of two reactions. The first one is fast, possibly representing the ligand binding to monomeric or dimeric aluminium species and the second represents the decomposition of the polymeric $\mathrm{Al}_{13}$-mer induced by the interaction of cacodylate to give simpler species, in agreement with the observed disaggregation of $\mathrm{Al}_{13}$-mer induced by ligands with oxygen containing groups, such as acetate, oxalate and lactate and, more 
conceivably, by protons. ${ }^{26,37-39}$ In this case, disaggregation seems to be strongly dependent on the $\mathrm{pH}$ and less on the ligand.

Furrer et $\mathrm{al}^{37}$ state that the disaggregation of $\mathrm{Al}_{13}-\mathrm{mer}$ is driven by the proton concentration. In other words, the only presence of cacodylate does not allow by itself the disaggregation of the aluminium oligomers under the experimental conditions $\left(\mathrm{C}_{\mathrm{L}} / \mathrm{C}_{\mathrm{M}}=1\right)$. However, ${ }^{1} \mathrm{H}$ NMR spectra (Fig. S4, ESI) show that excess of ligand causes an increase in the peak intensity associated to the complexed cacodylate. Thus, some competition between the inner and outer coordination spheres can be guessed in excess of ligand, where the first one can evolve to simpler forms by disruption of the polymer.

The results at $\mathrm{pH} 7$ significantly differ from the trend observed at $\mathrm{pH} 5$ and 6 . A very broad, low intensity, peak centred at $60 \mathrm{ppm}$ is obtained in ${ }^{27} \mathrm{Al}-\mathrm{NMR}$ spectra (Fig. 5A), and the ${ }^{1} \mathrm{H}-\mathrm{NMR}$ exhibits very small peaks of the complexed forms (Fig. 6B), even at same resonance of the peaks at $\mathrm{pH} 5$ and 6 . However, at $\mathrm{pH} 7$ no precipitation was observed in the $\mathrm{Al} / \mathrm{Cac}$ solution, whereas extended precipitation occurs for the free aluminium. Thus, we can envisage occurrence of interaction, even though of different nature compared to that at work at lower $\mathrm{pH}$ values.

Stumm ${ }^{40}$ suggested that the interaction of an organic ligand with a solid interface can be differentiated between inner (strong bonding) and outer (weak bonding) coordination sphere. In a study of the acetate/aluminium system ${ }^{41}$ it has been proposed that the interaction of the acetate ion with $\mathrm{Al}_{2} \mathrm{O}_{3}$ in suspension involves mainly the outer coordination sphere. ${ }^{37}$ We suggest that at $\mathrm{pH} 7$ cacodylate can interact with $\mathrm{Al}(\mathrm{III})$ aggregates in the same way as acetate reacts with aluminium oxide 
suspension. The resulting complex enables aluminium to remain in solution.

Determination of $\mathbf{K}_{\text {app }}$ of aluminium/cacodylate complexes. The apparent equilibrium constant, $K_{a p p}$, for formation of the aluminium/cacodylate (Al/Cac) complexes, was determined from batch-wise spectrophotometric titrations performed for different $\mathrm{pH}$ values. The apparent reaction is

$\mathrm{M}_{\mathrm{f}}+\mathrm{L}_{\mathrm{f}} \mathrm{ML}_{\mathrm{T}}$

where $\mathrm{M}_{\mathrm{f}}$ and $\mathrm{L}_{\mathrm{f}}$ are respectively the non-complexed free metal and the ligand forms, and $\mathrm{ML}_{\mathrm{T}}$ is the total complex. Most of the experimental data-pairs were obtained with no excess of metal or ligand. The interaction between aluminium species and cacodylate causes a hypochromic effect (Fig. 7A). The data-pairs were analysed according to eqn. (6):

where $\mathrm{C}_{\mathrm{L}}$ and $\mathrm{C}_{\mathrm{M}}$ are the analytical ligand and metal concentration, respectively, $\Delta \mathrm{A}=$ $\mathrm{A}-\varepsilon_{\mathrm{L}} \mathrm{C}_{\mathrm{L}}$ and $\Delta \varepsilon=\varepsilon_{\mathrm{ML}}-\varepsilon_{\mathrm{L}}$, where $\varepsilon_{\mathrm{i}}$ is the absorptivity of the $\mathrm{i}^{\text {th }}$ species. 


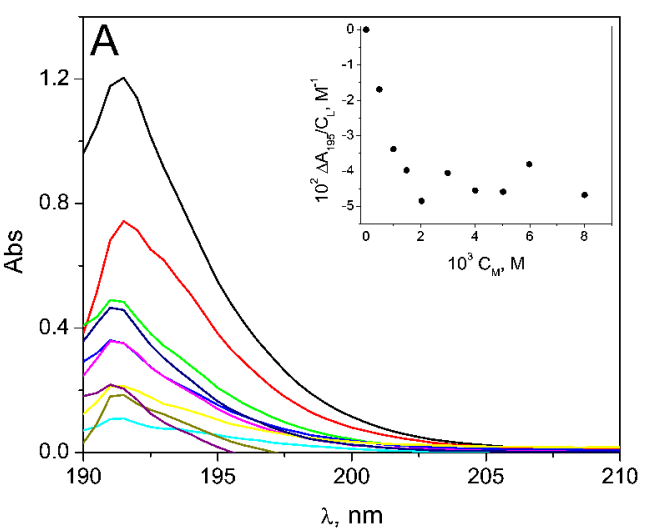




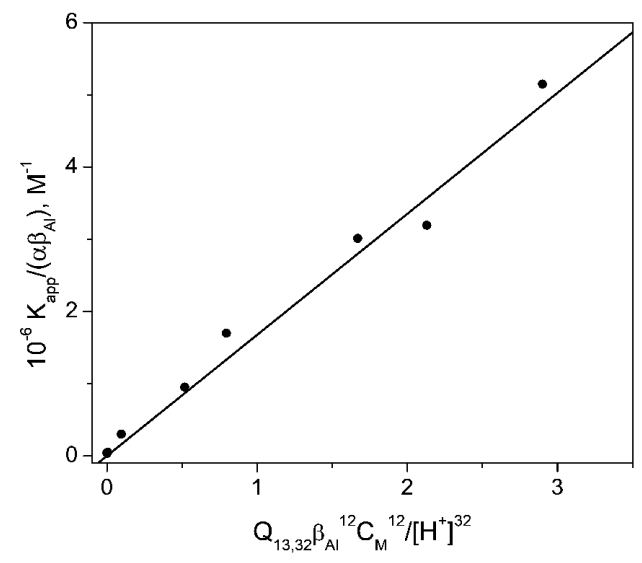

Fig. 7 (A) Example of spectrophotometric titration of the $\mathrm{Al} / \mathrm{Cac}$ system. Inset: track at $\lambda=195 \mathrm{~nm}$. $\mathrm{C}_{\mathrm{L}}=1.0 \times 10^{-3} \mathrm{M}, \mathrm{I}=0.1 \mathrm{M}, \mathrm{pH}=4.8$ and $\mathrm{T}=25.0^{\circ} \mathrm{C}$. (B) Analysis according to eqn (8) of the 4.3 $<\mathrm{pH}<5.0$ data.

Different binding isotherms were obtained using absorbance values within 195-205 nm (Fig. 7A), a range where aluminium ion displays no absorption, whereas the different dimethylarsinic forms have different absorptivity, $\varepsilon_{i}$. The equilibrium constants obtained (Table 1) are averaged values. At $\mathrm{pH}=2$, such evaluation was unfeasible because the change in absorbance was too modest owing to the repression of the binding reaction caused by protons, and in agreement with the NMR results.

Table 1. Apparent equilibrium constant for binding of aluminium to cacodylate $\left(\mathrm{K}_{\mathrm{app}}\right)$ at different $\mathrm{pH} . \mathrm{I}=0.1 \mathrm{M}$ and $\mathrm{T}=25^{\circ} \mathrm{C}$. 


\begin{tabular}{|c|c|}
\hline $\mathbf{p H}$ & $\mathbf{K}_{\mathbf{a p p}} \mathbf{( \mathbf { M } ^ { - 1 } )}$ \\
\hline 3.00 & $25 \pm 5$ \\
\hline 4.00 & $290 \pm 50$ \\
\hline 4.30 & $560 \pm 60$ \\
\hline 4.48 & $2200 \pm 300$ \\
\hline 4.70 & $3400 \pm 600$ \\
\hline 4.78 & $4600 \pm 900$ \\
\hline 4.90 & $5400 \pm 1000$ \\
\hline 4.95 & $4800 \pm 1000$ \\
\hline 5.00 & $6500 \pm 1000$ \\
\hline & \\
\hline
\end{tabular}

The relationship between $\mathrm{K}_{\mathrm{app}}$, and $\left[\mathrm{H}^{+}\right]$is expressed by eqn (7) (see ESI)

where $\alpha_{\mathrm{L}}$ is the molar fraction of the species $\mathrm{Cac}^{-}, \beta_{\mathrm{Al}}$ is the molar fraction of the species $\mathrm{Al}^{3+}, \mathrm{K}^{\mathrm{I}}, \mathrm{K}^{\mathrm{II}}, \mathrm{K}^{\mathrm{III}}, \mathrm{K}^{\mathrm{IV}}, \mathrm{K}^{\mathrm{V}}, \mathrm{K}^{\mathrm{VI}}, \mathrm{K}^{\mathrm{VII}}$ and $\mathrm{K}^{\mathrm{VIII}}$ are the equilibrium constants for binding of $\mathrm{Cac}$ to $\mathrm{Al}^{3+}, \mathrm{Al}(\mathrm{OH})^{2+}, \mathrm{Al}(\mathrm{OH})_{2}{ }^{+}, \mathrm{Al}(\mathrm{OH})_{3}, \mathrm{Al}(\mathrm{OH})_{4}{ }^{-}, \mathrm{Al}_{2}(\mathrm{OH})_{2}{ }^{4+}$, $\mathrm{Al}_{3}(\mathrm{OH})_{4}{ }^{5+}$ and $\mathrm{Al}_{13} \mathrm{O}_{4}(\mathrm{OH})_{24}{ }^{7+}$, respectively. On the other side, the values (Fig. 3) support simplification of eqn (7) to eqn (8). In fact, all contributions, except those of $\mathrm{Al}^{3+}$ and $\mathrm{Al}_{13}$-mer, are negligible for, under the employed experimental conditions, the mole fraction of the other species is low.

Moreover, since formation of the polymeric form is fully attained within a very narrow $\mathrm{pH}$ range, two well defined $\mathrm{pH}$ ranges can be distinguished; in the first $(3.0<\mathrm{pH}<4.3)$ the monomers $\mathrm{Al}^{3+}$ and $\mathrm{AlOH}{ }^{2+}$ are active, while in the second $(4.7<\mathrm{pH}<5.0)$ the $\mathrm{Al}_{13}$-mer is active. For $\mathrm{pH}>4.5$, the contribution of $\mathrm{K}^{\mathrm{I}}$ to eqn $(8)$ is negligible (Fig. 7B). In this $\mathrm{pH}$ range, $\log \left[\mathrm{K}_{\mathrm{app}} /\left(\mathrm{LAl}^{13}\right)\right]$ versus $\mathrm{pH}$ plots at different $\mathrm{C}_{\mathrm{M}}$ (Fig. S5 A, ESI), and $\log \left[\mathrm{K}_{\mathrm{app}}\left[\mathrm{H}^{+}\right]^{32} /\left(\mathrm{LAl}^{13}\right)\right]$ versus $\mathrm{C}_{\mathrm{M}}$ plot (Fig. S5 B, ESI) 
yielded straight lines with slope equal to 32 and 12, respectively, reinforcing the presence of $\mathrm{Al}_{13} \mathrm{O}_{4}(\mathrm{OH})_{24}{ }^{7+}$ as the reactive species. Analysis according to eqn (8) of $\mathrm{K}_{\text {app }}$ versus $\mathrm{pH}$ plots yielded $\mathrm{K}^{\mathrm{VIII}}=(1.6 \pm 0.4) \times 10^{6} \mathrm{M}^{-12}$ (Fig. 7B). This datum can be used in the $3.0<\mathrm{pH}<4.3$ region to evaluate $\mathrm{K}^{\mathrm{I}}=(4 \pm 2) \times 10^{4} \mathrm{M}^{-1}$.

Also, from the NMR data obtained we evaluated the apparent equilibrium constant at $\mathrm{C}_{\mathrm{L}}=\mathrm{C}_{\mathrm{M}}$ and different $\mathrm{pH}$ values (see ESI). The $\mathrm{K}_{\text {app }}$ values obtained at $\mathrm{pH}$ values 4 and 5 (Table 1 ESI) concur well with the spectrophotometric values (Table 1). However, the values obtained at $\mathrm{pH} 6$ and 7 are smaller than expected, thus disagreeing with the model proposed by means of UV measurements (Fig. 6 ESI) due to the observed aggregation trend of the $\mathrm{Al}_{13}$ units.

${ }^{27} \mathrm{Al}-\mathrm{NMR}$ results show that the interaction between metal and ligand yield the AlCac complex and not $\mathrm{AlHCac}$ or $\mathrm{AlH}_{2} \mathrm{Cac}$, however no indication is provided as to forming AlCac from reactions (9) or (10) written below.

$$
\mathrm{Al}^{3+}+\mathrm{Cac}^{-}=\mathrm{AlCac}^{2+}
$$

Due to the proton ambiguity, reaction (9) cannot be thermodynamically distinguished from the equivalent reaction (10)

$$
\mathrm{AlOH}^{2+}+\mathrm{HCac}=\mathrm{AlCac}^{2+}
$$

Being $\mathrm{AlOH}^{2+}$ about $10^{4}$-fold more reactive than $\mathrm{Al}^{3+}$ aquo ion, as results from comparison of the respective rates of water exchange [REF Nordin JP, Sullivan DJ et al. Inorg Chem 1998 37(19) 4760-4763 An 17O-NMR study of the exchange...] the 
first step of the $\mathrm{Al}(\mathrm{III})$ binding to a chelating ligand should be about $10^{3}$-fold faster in the case of $\mathrm{AlOH}^{2+}$.[REF Secco venturini Inorg. Chem. 1975 Mechanism of Complex formation.Reaction between Aluminum and Salycilate ions] Hence, for $\mathrm{pH}>2$ the formation of $\mathrm{AlCac}^{2+}$ will undergo mainly through reaction (10). The equilibrium constant of reaction (10), here denoted as $\mathrm{K}^{\mathrm{I}}$, is related to $\mathrm{K}^{\mathrm{I}}$ by the relationship $\mathrm{K}^{\mathrm{I}}$ = $\mathrm{K}^{\mathrm{I}} \mathrm{K}_{\mathrm{A} 2} / \mathrm{Q}_{11}$. Its value is $\mathrm{K}^{\mathrm{I}}$, $=\left(\begin{array}{ll}8 & 4\end{array}\right) \times 10^{3} \mathrm{M}^{-1}$. Only for $\mathrm{pH}>5$ the contribution of the deprotonated $\mathrm{Cac}^{-}$ion to the binding reaction becomes important. This interpretation differs from that advanced in a previous study were the formation of the 1:1 complex was rationalized assuming that the main process is the reaction of the $\mathrm{Al}^{3+}$ ion with the deprotonated form of the ligand, $\mathrm{Cac}^{-} \cdot{ }^{19}$

DFT calculations: hypothesis of $\mathrm{Al} / \mathrm{Cac}$ structures. By means of the mass spectrometry and NMR data, we have hypothesized possible $\mathrm{Al} / \mathrm{Cac}$ structures. It can reasonably be assumed that the ligand chelates the metal, as demonstrated for other oxygenated ligands with aluminium..$^{26,41,42}$

The suggested structure of the monomer species is shown in Fig. 8A (note that water molecules can be replaced by hydroxo groups, and more than one ligand could be present). For the dimer species, the mass spectrometry and NMR data gathered do not clarify the exact structure, so different geometries can be considered. Based on earlier studies on different $\mathrm{Al}(\mathrm{III})$ complexes, ${ }^{31,41}$ we propose the following structures: two aluminium atoms linked by two oxygen groups (Fig. 8B), the interaction of the aluminium complexes is obtained via hydroxo groups (Fig. 8C), only one oxygen binds the aluminium complexes, as in the third structure (Fig. 8D). Interestingly, a different $\mathrm{M}_{2} \mathrm{~L}$ structure is proposed for the aluminium/acetate complex. ${ }^{41}$ Since cacodylate 
exhibits similar structure as the acetate, we proposed similar geometry associated to the most intense signal in the mass spectrometry $(\mathrm{m} / \mathrm{z}=121)$ and NMR spectra $(\delta=$ 1.95 and $1.80 \mathrm{ppm}$ ) (Fig. 8E). As a matter of fact, a syn-syn bridging geometry is considered by the experimental results, where the two oxygens bind to both aluminium atoms of the dimeric form. Hence, a double hydroxo- or oxo- bridged geometry is present. For the trimeric and tetrameric species, other more complex structures can be hypothesized with the same bridging geometry.
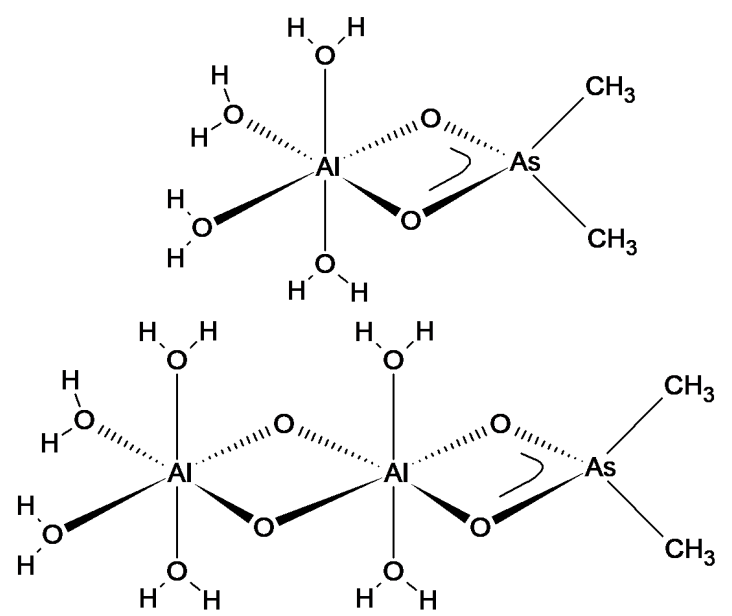

A
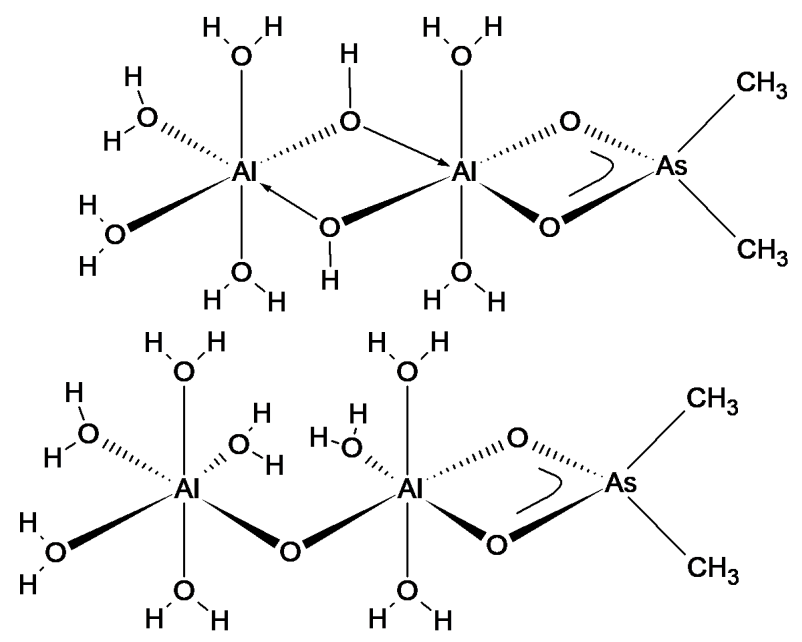

$\mathrm{C}$

D 


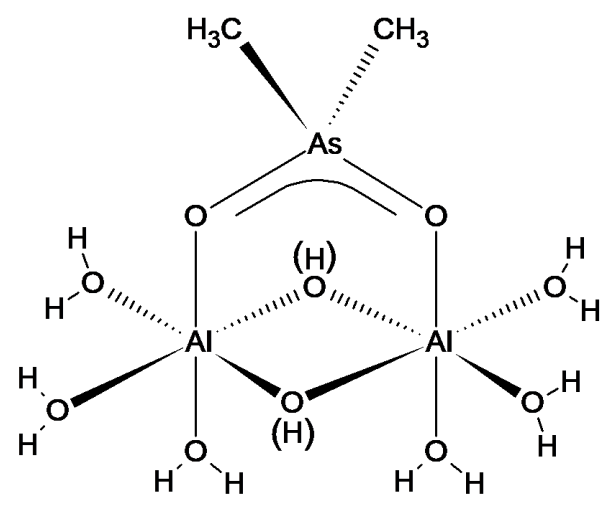

$\mathrm{E}$

Fig. 8 (A) 1:1 structure. (B) First 2:1 structure. (C) Second 2:1 structure, (D) Third 2:1 structure (E) Fourth 2:1 structure: syn-syn bridging geometry.

To convincingly justify the hypotheses drawn on the dimeric complexes, we undertook theoretical energy calculations of these complexes.

For the $\mathrm{M}_{2} \mathrm{~L}$ dimeric system, four different structures were calculated (B,C and two more E structures, with and without bridging oxygens, which will be denoted as $\mathrm{E}(\mathrm{OH})$ and $\mathrm{E}(\mathrm{O})$, respectively. The two $\mathrm{E}$ structures consist of a 2:1 complex, where Cacodylate is bound to only one $\mathrm{Al}$ atom via a double O-bridge. $\mathrm{B}$ and $\mathrm{C}$ structures resemble the $\mathrm{E}(\mathrm{O})$ and $\mathrm{E}(\mathrm{OH})$ structures, respectively, but with $\mathrm{OH}$ bridging ligands between $\mathrm{Al}$ atoms, instead of O-bridge, and two more hydroxo ligands.

The stability has been studied in terms of the overall energy (products energy). The DFT optimization of these structures results in the stability sequence, from most stable to less stable (Hartree units), as follows: (B) $(-849.660435)>$ (C) $(-849.651503)>(\mathrm{E}(\mathrm{O}))(-849.590124)>(\mathrm{E}(\mathrm{OH}))(-849.558751)$. Thus, the most stable structure involves $\mathrm{OH}$-bridging ligands between $\mathrm{Al}$ atoms with cacodylate bound to both metal centres. The optimized structure of $(\mathrm{E}(\mathrm{OH})$ is plotted in Fig. 9A. 
A

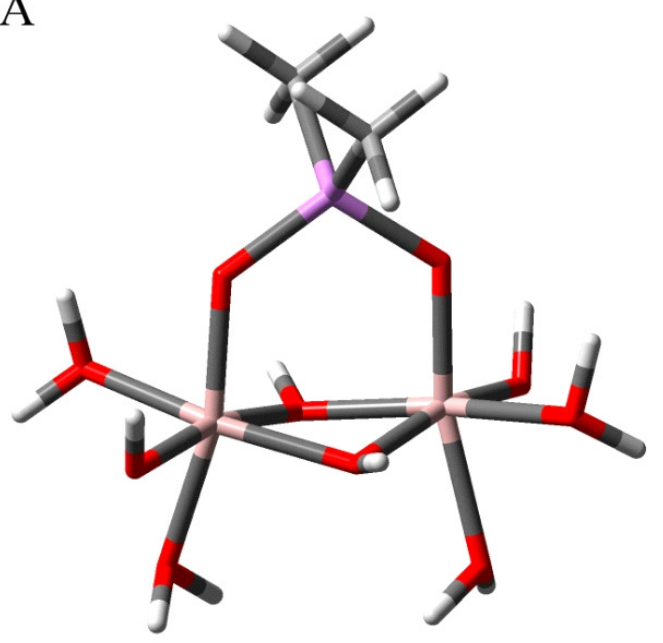

B

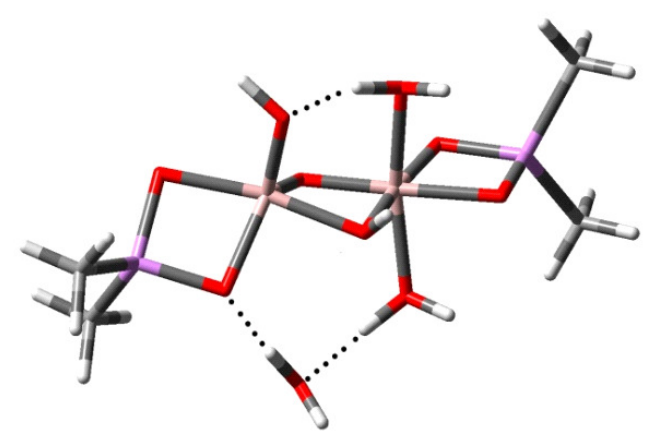

Fig. 9 (A) DFT optimization of structure E(OH) in water, using B3LYP functional with 6-31G(d) basis set for $\mathrm{C}$ (grey), $\mathrm{H}$ (white) and $\mathrm{O}$ (red) atoms, and LANL2DZ for Al (pink) and As (purple) atoms. (B) DFT optimization of 2:2 linear complex in water, using B3LYP functional with 6-31G(d) basis set for $\mathrm{C}$ (grey), $\mathrm{H}$ (white) and $\mathrm{O}$ (red) atoms, and LANL2DZ for Al (pink), As (purple) atoms and H-bonding interactions (dashed lines).

A non-symmetrical conformation has been obtained (symmetry group C1) with $\mathrm{OH}$ groups in the Al-Al plane pointing to cacodylate group. Surprisingly, methyl groups bound to As, adopted eclipsed conformation. Full NBO (Natural Bond Orbital) analysis has revealed that, as expected, the $\mathrm{Al}$ and As sites are mainly positively 
charged. Oxygen atoms in the Al-O-As bonds are significantly more negative than the others due to the charge donating nature of the metals. Thus, the Oxygen site in the $\mathrm{OH}$-bridges between $\mathrm{Al}$ atoms are, indeed, more negative than those on the water molecules.

The characterization parameters (bond distance and angle) of the "core" of the molecule (every atom surrounding $\mathrm{Al}$ and As atoms) are compiled in Table S2, ESI. The two atom distances and angles containing $\mathrm{Al}$ are similar, showing that the core lies in a symmetric environment and the abovementioned asymmetry is due to the slightly asymmetric conformation of the $\mathrm{H}_{2} \mathrm{O}, \mathrm{OH}$ and $\mathrm{CH}_{3}$ groups.

In addition, DFT optimization and geometry analysis of two 2:2 complex (structures reported in Fig. S7, ESI), has been carried out, whose presence was confirmed by mass spectrometry $(\mathrm{m} / \mathrm{z}=361)$. Since the calculations of a double synsyn bridging geometry complex (Fig. S7 A, ESI) proved to be unstable in water, complex linear geometry (Fig. S7 B, ESI) has been DFT optimized to a minimum energy state $(E=-933.31$ Hartrees $)$. In the final conformation, one hydrogen atom from a water molecule is lost, and transferred to one of the O-bridging ligand between $\mathrm{Al}$ atoms. Moreover, a full water molecule is lost, remaining nearby the 2:2 complex via H-bonding interaction (Fig. 9B). These rearrangements, result in a surprisingly different conformation for $\mathrm{Al}$ atoms, from the initial $\mathrm{Al}$ (octhedral)-Al(octahedral) to $\mathrm{Al}$ (pyramidal)-Al(octahedral). The stabilization of the pyramidal configuration can be explained by the H-bonding induced by the above mentioned water molecule that falls off the molecule (Table S3, ESI), showing that expected symmetry of the optimized structure is totally lost. The distance and angle values of the Al-O bonds considerably differ from their theoretical mirror image bonds. The dihedral angles show different 
orientation of the As-O-Al(pyramidal)-O and As-O-Al(octahedral) rings compared to the plane containing $\mathrm{Al}(1), \mathrm{O}(2)$ and $\mathrm{Al}(3)$; the $\mathrm{Al}$ (pyramidal) ring is primarily orientated to the yz plane, whereas the $\mathrm{Al}$ (octahedral) containing ring, lies in the $\mathrm{xz}$ plane. As described for the 2:1 complex, the NBO analysis displays electron donation from metals to oxygen, an effect more intense for the O-bridging ligands between $\mathrm{Al}$ atoms.

\section{Conclusion}

Thermodynamic experiments of the interaction between $\mathrm{Al}(\mathrm{III})$ and dimethylarsinic acid suggest that the apparent binding affinity has a maximum in the 5-6 $\mathrm{pH}$ region, whereas at $\mathrm{pH} 4$ and $\mathrm{pH} 7$ the binding strength is low. Comparison of the MS and NMR data suggests that the main species formed is a 2:1 complex. Thus, the most probable effect is that the 1:1 complex, which forms first, has a high affinity for a second aluminium ion. In particular, the most plausible structure is the dimeric syn-syn bridging geometry structure of the cacodylate, interacting with the two aluminium centres (Fig. 8E). On the other hand, the different behaviour observed at $\mathrm{pH} 7$ respect to that at $\mathrm{pH} 4-6$ is explained assuming the formation of an outer sphere coordination of the ligand to the $\mathrm{Al}_{13}$ aggregates at neutral $\mathrm{pH}$, thus avoiding precipitation. On the other hand, at lower $\mathrm{pH}$ the polymeric form disintegrates into small molecules, an effect promoted mainly by the proton and, to a less extent, by the ligand. Elucidation of the $\mathrm{A} / \mathrm{Cac}$ complex, which does not allow aluminium to precipitate, can be very useful to obtain a system available to study the biological processes and molecular mechanisms that underlie pathological effects induced by aluminium ions. 


\section{Acknowledgements}

This work was supported by Obra Social "la Caixa" (OSLC-2012- 007), and

MINECO, CTQ2014-58812-C2-2-R projects, Spain

\section{Notes and References}

1. C. F. Baes and R. E. Mesmer, in Hydrolysis of Cations, John Wiley \& Sons, New York1976, ch. 6, pp. 112-123.

2. M. Lamberti, I. D'Auria, M. Mazzeo, S. Milione, V. Bertolasi and D. Pappalardo, Organometallics, 2012, 31, 5551-5560.

3. J. I. Mujika, J. M. Ugalde and X. Lopez, Phys. Chem. Chem. Phys., 2012, 14, 12465-12475.

4. S. Bhattacharjee, Y. Zhao, J. M. Hill, F. Culicchia, T. P. A. Kruck, M. E. Percy, A. I. Pogue, J. R. Walton and W. J. Lukiw, J. Inorg. Biochem., 2013, 126, 35-37.

5. T. Kiss, J. Inorg. Biochem., 2013, 128, 156-163.

6. A. Strunecka, R. L. Blaylock and J. Patocka, Curr. Inorg. Chem., 2012, 2, 8-18.

7. C. Exley and J. D. Birchall, J. Theor. Biol., 1992, 159, 83-98.

8. E. H. Jeffery, K. Abreo, E. Burgess, J. Cannata and J. L. Greger, J. Toxicol. Env. Health, 1996, 48, 649-665.

9. S. A. Latt and H. A. Sober, Biochemistry, 1967, 6, 3307-3314.

10. B. Holmberg., Z. Phys. Chem., 1910, 70, 153-158.

11. J. Juillard and N. Simonet, Bull. Soc. Chim. Fr., 1968, 1883-1894.

12. K. B. Jacobson, B. D. Sarma and J. B. Murphy, FEBS Lett., 1972, 22, 80-82.

13. T. W. Shin, K. Kim and I. J. Lee, J. Solution Chem., 1997, 26, 379-390.

14. H. Diebler, F. Secco and M. Venturini, Biophys. Chem., 1987, 26, 193-205.

15. P. V. Ioannou, Monatsh. Chem., 2012, 143, 1349-1356.

16. P. V. Ioannou, Z. Anorg. Allg. Chem., 2010, 636, 1347-1353.

17. C. F. Whittemore and C. James, J. Am. Chem. Soc., 1913, 35, 127-132.

18. R. Pietsch, Microchim. Acta, 1958, 220-224.

19. P. V. Ioannou, Monatsh. Chem., 2013, 144, 793-802.

20. M. Lashkari and M. R. Arshadi, Chemical Physics, 2004, 299, 131-137.

21. M. J. Frisch, G. W. Trucks, H. B. Schlegel, G. E. Scuseria, M. A. Robb, J. R. Cheeseman, G. Scalmani, V. Barone, B. Mennucci, G. A. Petersson, H. Nakatsuji, M. Caricato, X. Li, H. P. Hratchian, A. F. Izmaylov, J. Bloino, G. Zheng, J. L.

Sonnenberg, M. Hada, M. Ehara, K. Toyota, R. Fukuda, J. Hasegawa, M. Ishida, T. Nakajima, Y. Honda, O. Kitao, H. Nakai, T. Vreven, J. A. Montgomery, J. E. Peralta, F. Ogliaro, M. Bearpark, J. J. Heyd, E. Brothers, K. N. Kudin, V. N. Staroverov, R. Kobayashi, J. Normand, K. Raghavachari, A. Rendell, J. C. Burant, S. S. Iyengar, J. Tomasi, M. Cossi, N. Rega, J. M. Millam, M. Klene, J. E. Knox, J. B. Cross, V. Bakken, C. Adamo, J. Jaramillo, R. Gomperts, R. E. Stratmann, O. Yazyev, A. J. Austin, R. Cammi, C. Pomelli, J. W. Ochterski, R. L. Martin, K. Morokuma, V. G. Zakrzewski, G. A. Voth, P. Salvador, J. J. Dannenberg, S. Dapprich, A. D. Daniels, Farkas, J. B. Foresman, J. V. Ortiz, J. Cioslowski and D. J. Fox, Gaussian, Inc., Revision B.01 edn., 2009. 
22. K. Yates and H. Wai, J. Am. Chem. Soc., 1964, 86, 5408-5413.

23. M. L. Kilpatrick, J. Am. Chem. Soc., 1949, 71, 2607-2610.

24. G. Furrer, C. Ludwig and P. W. Schindler, J. Colloid Interf. Sci., 1992, 149, 56-67.

25. C. Ye, Z. Bi and D. Wang, Colloids and Surfaces A, 2013, 436, 782-786.

26. W. H. Casey, Chem. Rev., 2006, 106, 1-16.

27. J. W. Eaton, D. Bateman and S. Hauberg, in A High-Level Interactive Language for Numerical Computations, Create Space Independent Publishing Platform, 3.0.1 edn., 2009.

28. M. H. Florencio, M. F. Duarte, A. M. M. deBettencourt, M. L. Gomes and L. F. V. Boas, Rapid Commun. Mass Sp., 1997, 11, 469-473.

29. H. R. Hansen, A. Raab and J. Feldmann, J. Anal. Atom. Spectrom., 2003, 18, 474-479.

30. T. Urabe, M. Tanaka, S. Kumakura and T. Tsugoshi, J. Mass Spectrom., 2007, 42, 591-597.

31. A. Sarpola, V. Hietapelto, J. Jalonen, J. Jokela and R. S. Laitinen, J. Mass Spectrom., 2004, 39, 423-430.

32. A. T. Sarpola, V. K. Hietapelto, J. E. Jalonen, J. Jokela and J. H. Ramo, Int. J. Environ. An. Ch., 2006, 86, 1007-1018.

33. A. Sarpola, V. Hietapelto, J. Jalonen, J. Jokela, R. S. Laitinen and J. Ramo, J. Mass Spectrom., 2004, 39, 1209-1218.

34. T. Urabe, T. Tsugoshi and W. Tanakaa, J. Mass Spectrom., 2009, 44, 193-202.

35. J. W. Akitt and B. E. Mann, J. Magn. Reson., 1981, 44, 584-589.

36. J. J. Fitzgerald, L. E. Johnson and J. S. Frye, J. Magn. Reson., 1989, 84, 121-133.

37. G. Furrer, M. Gfeller and B. Wehrli, Geochim. Cosmochim. Acta, 1999, 63, 3069-3076.

38. A. Masion, F. Thomas, D. Tchoubar, J. Y. Bottero and P. Tekely, Langmuir, 1994, 10, 4353-4356.

39. A. Amirbahman, M. Gfeller and G. Furrer, Geochim. Cosmochim. Acta, 2000, 64, 911-919.

40. W. Stumm, in Chemistry of the solid-water interface: processes at the mineral-water and particle-water interface in natural systems, John Wiley \& Sons, New York1992, ch. 1, pp. 4-8.

41. P. Persson, M. Karlsson and L. O. Ohman, Geochim. Cosmochim. Acta, 1998, 62, 3657-3668.

42. R. B. Martin, Clin. Chem., 1986, 32, 1797-1806. 